\title{
Humanism and nature - some reflections on a complex relationship
}

\author{
JÖRN RÜSEN*
}

\begin{abstract}
The paper starts with a systematical analysis of the interrelationship of humanism and nature. It proceeds to a historical reconstruction of this relationship in the development of Western humanism from ancient Rome via Renaissance till the Enlightenment of the $18^{\text {th }}$ century. In both respects the result of the analysis is the same: The Western tradition of humanism is characterised by a gap between an emphasis on the cultural quality of human life on the one hand and nature on the other one. Men are entitled to dominate and govern nature and use it for their purpose. This fits into an idea of a progressing destructive relationship between man and nature in the West. On the other the tradition of humanism has put the gap between man and nature into a harmonising cosmological or theological context. In this context a simple destructive relationship between man and nature is not possible. The humanism of today has to pick up the challenge of the ecological crisis and to refer to its tradition where man and nature are mediated into a meaningful and sense-bearing interrelationship. Instead of simply referring to the traditional cosmology a convincing idea of this mediation or even synthesis can only be made plausible by referring to the already pre-given synthesis between nature and culture, the human body.
\end{abstract}

Keywords: Humanism, nature, humanity, Kant, Herder, subjugating nature, human dignity, Bildung, culture, aesthetisation of nature, renaturalisation of human culture, transcultural universalism.

Unter allen Tieren ist das Geschöpf der feinsten Organe, der Mensch, der größte Mörder ... Im Menschenreich ... herrscht die größte Mannigfaltigkeit von Neigungen und Anlagen, die wir oft als wunderbar und widernatürlich anstaunen ... Da nun auch diese nicht ohne organische Gründe sein können, so ließe sich ... das Menschengeschlecht als der große Zusammenfluß niederer organischer Kräfte ansehen, die in ihm zur Bildung der Humanität kommen sollten ... Der größste Teil der Menschen ist Tier; zur Humanität hat er bloß die Fähigkeit auf die Welt gebracht und sie muß ihm durch Mühe und Fleiß erst angebildet werden.

Herder $^{1}$

* President of the Institute for Advancved studies in the Humanities (KWI), Essen, Germany and Extraordinary Professor NWU, Vaal Triangle Faculty. Leader of the New Humanism project and co-organiser of the conference Humankind and Nature at the Intersection of Culture, Kruger National Park, South Africa.

1 Translation: Among all animals man, the creature with the most elaborate organs, is the biggest murderer ... In the realm of humankind there is the biggest variety of incli-nations and potentials which we often marvel at as ... wonderful and unnatural ... Since even these can't exist without organic reasons, we may look at the human race as a great confluence of minor organic powers which are supposed to develop into humanity within it ... The largest part of man is animal; he was only born with the ability for humanity, and it has to be developed within him by hard educational work. JG Herder, Ideen zur Philosophie der Geschichte der Menschheit Werke, Vol. III/ 1, ([Ed. Wolfgang Pross] Wissenschaftliche Buchgesellschaft Darmstadt, 2002), pp. 164, 166, 180. 


\section{What has humanism to do with nature?}

What has humanism to do with nature or even with ecology? In order to answer this question I would like to start with some remarks about what humanism is ${ }^{2}$ : Humanism is an idea of the cultural nature of human beings, an attitude of intersubjectivity and a historical tradition mainly in the West referring to certain values and forms of discourse. As an idea it emphasizes specific values which are ascribed to all humans in all times and spaces. At the core of these values there is a high esteem of the simple fact that somebody is human. In the West we call that core value human dignity. In his philosophy of morality Immanuel Kant expressed it in the following way: Each human being should not only be considered as a means for purposes of somebody else, but as a purpose in him- or herself. ${ }^{3}$

Evidently, in this description of humanism 'nature' does not occur. On the contrary: Humanism exclusively refers to all those attributes and qualities of man by which he or she essentially differ from nature. But nevertheless, this difference is a reference, and it has a lot of consequences for human self-understanding and the attitude of man towards nature.

Thus, the first reference of humanism to nature is owed to the humanistic idea of what it means to be a human being. Here the difference made between nature and culture is decisive: The special values ascribed to the humans are an essential cultural matter and not a natural one. In the older idea of humanism it might be given to man by nature, but with their culture humans transgress the realm of nature and become a species of its own, essentially being different from all other natural beings. This repeats and confirms the first reference.

A second reference to nature can be detected in the topical discussion about humanism. Here humanism is defined as the opposite of naturalism, which means that we cannot understand what humans are by simply referring to their biological qualities.

A third reference to nature occurs in the discussion about humanism, as soon as the ecological crisis of today comes up. Here we can find arguments pointing at an inbuilt destructive element in the Western tradition of humanism. It says that in this tradition man are put into a relationship to nature which is defined by exploitation and destruction. Humanism is accused of being a cultural reason for the

2 H Cancik, "Humanismus", in H Cancik, B Gladigow, H-K Kohl, (Eds): Handbuch religionswissenschafticher Grundbegriffe. Bd. III. (Kohlhammer, Stuttgart, 1993), pp. 173-185.

3 I Kant: Metaphysik der Sitten, (Akademie-Ausgabe), Vol. VI, p. 434 sq. 
disastrous form in which the culture of modernity refers to nature. It is said to have brought about the crisis or even the catastrophe of our ecological situation. By emphasizing the dignity of man humanism renounces an acceptable relationship of man and nature. Descartes' idea that man is 'master and owner of nature' (maitre et posesseur de la nature) expresses this relationship. It robs human life of its natural quality as being part of an overall encompassing nature.

Fourth and finally nature becomes an issue of discussion when we look for principles and rules to which we can and must refer when we want to heal the disturbed relationship to nature striving for an order which guarantees the physical survival of humankind.

In my following argumentation I will tackle these four points of reference. By doing so, I hope that I can sketch an idea of humanism which may reconcile humankind and humanity as a key issue of our cultural self-understanding and orientation of our lives.

\section{Nature and culture in humanism}

In the modern understanding of humanism nature is a counter-concept of humanity. By speaking of 'humanity' as a principle of human self-understanding and as a guideline of human practical life, humanism emphasizes the cultural quality of men by which it essentially differs from nature, let alone from all other species in the visible world. Herder expressed this trans-natural 'nature' of humankind by addressing men as "Freigelassene der Schöpfung" (released slaves of the creation). This has to be understood as being liberated from the constraints of nature, from the submission to the commands of its laws.

Man has brought about another order of life with new laws, namely the laws of reason and morality, the commitment to that which defines the humanity of humans. Different from all other natural beings which were thrown into a pre-given order of life men, have created this order themselves facilitated by the competence of generating the sense criteria of their lives themselves. Realizing this competence in the manifold manifestations of culture, human life has to be understood as a process of bringing about one's own human character. Humanity is a process of self-empowerment of humans which goes beyond all natural limits and leads to the world of culture.

Culture is the contrary of nature. It is constituted by a set of values and norms which have to be ascribed to every single member of the human race. This set of values has changed in the course of time, but some common features nevertheless can be enumerated: The idea of equality, the entitlement to basic rights, social solidarity as a consequence of the fragility of human life, and the general moral rule that

TD, 2(2), December 2006, pp. 265-276. 
the values and norms, which a person or social group feels entitled to or committed to should be valid for each other person and social group as well.

This emphasis on culture humanism can be characterized as transnatural understanding of man. The ability to follow rules generates the moral character which originates in cultural processes of sense generation.

\section{The challenge of naturalism}

It is this emphasis on a normative concept of the 'cultural nature of man' which puts humanism in a strict contrast and opposition to all tendencies of naturalizing human nature. For naturalism the human world is exclusively defined with reference to the biological attributes of the human race. Today humanism is challenged by a powerful biological determinism in understanding the human world which refers to the genetic conditions of human life and its regulation by the physiological procedures of the human brain.

In this respect humanism can be understood and actually presents itself as a critique of such a concept of human nature. ${ }^{4}$ It claims a non-natural character of human life in so far as it is pursued in forms of practical life and social relationship, where all participants refer to cultural orientations. By this reference they can understand each other and give reason for what they are doing, suffering and failing. $\mathrm{Hu}-$ manism makes human life understandable by referring to (subjective) reasons for what the people do and not to (objective) the causes of their doing. Humanism emphasizes human subjectivity as a constitutive element for the understanding of the human world, whereas naturalism refers to conditions and determinations of human life, which have an external relationship to human subjectivity. Humanism insists on the values, norms and rules of human culture which cannot be replaced by scientific knowledge. Humanism insists on the principal difference between cultural knowledge humans always use in giving their lives meaning and significance on the one hand and the logic of scientific knowledge and its rational explanation by referring to causal laws.

\section{Is humanism an attitude of subjugating nature?}

In this respect humanism emphasizes the difference between man and nature. By doing so it creates, or at least, supports cultural

4 Cf. D Sturma (Ed.), Philosophie und Neurowissenschaften, (Suhrkamp, Frankfurt am Main, 2006). 
attitudes by which man refer to nature as a matter of domination and possession, as a matter of subjugation. Is humanism therefore nothing but an ideology of human mastery over nature which finally ends in the ecological catastrophe of today? This simple question demands a rather complex answer.

First of all, one has to emphasize that in the world-view of pre-modern times it was nature itself in its divine dimension which shaped human life and gave it a constitutive cultural feature characterized by general norms of dignity, benevolence, and solidarity. In this understanding nature has a divine quality by which it brings about culture. In its deepest ground nature is already culture, but nevertheless it is a separation from nature which defines the specificity of humanity.

The strong emphasis on education as a form of self-creation or selfcultivation of every human being may serve as evidence for this separation. Because of the effects of this cultivation man has a higher value then all other natural beings. Wild animals are cruel by nature. Humans can be humane by means of their culture.

In the philosophical context of ancient Roman humanism non-human nature was made for the sake of the gods and humans. Animals are created for the benefit of man. He can eat them. Men share with the animals the force of drives, but the human ability of reason separates them from them and the rest of nature. Reason has to govern the natural drives. "All dominion ... over the resources of the earth belongs to man." And it is this superiority which constitutes human dignity according to Cicero. ${ }^{6}$

So already in its antique origins Western humanism included the idea that man subjugates and dominates nature. ${ }^{7}$ This way of thinking reflects the urban civilization of a city where human life is no longer close to nature though its original base was grounded on agriculture.

This attitude did not change in early modern history, when the humanists referred to the idea of creation. Here God put humans in the centre of the world and enabled them to relate the whole of creation for themselves since in humankind the cosmos reflects itself in its sense-bearing order. At the same time humans are entitled to create the order of their world on their own. We can find this idea in Pico

5 Cicero, De Natura Deorum (On the Nature of the Gods), (Trans. Francis Brooks, Methuen, London, 1896), pp. II, 60, 152.

6 H Cancik, "Entrohung und Barmherzigkeit, Herrschaft und Würde. Antike Grundlagen von Humanismus" in R Faber (Ed.), Streit um den Humanismus, (Königshausen und Neumann, Würzburg, 2003), pp. 23-41, quotation p. 33.

7 Ibid., p. 30.

TD, 2(2), December 2006, pp. 265-276. 
della Mirandola's famous "Oration on the Dignity of Man" (1486/87), where God says to his creation, man:

The nature of all creatures is defined and restricted within laws which We have laid down; you, by contrast, impeded by no such restrictions, may, by your own free will, to those whose custody We have assigned you, trace for yourself the lineaments of your own nature. I have placed you at the very center of the world, so that from that vantage point you may with greater ease glance round about you on all that the world contains ... You may with greater erase glance round about you on all that the world contains ... You may, as the free and proud shaper of your own being, fashion yourself in the form you may prefer. It will be in your power to descend to the lower, brutish forms of life; you will be able, through your own decision, to rise again to the superior orders whose life is divine. ${ }^{8}$

Within a pre-given religious order governed by divine law, men form the centre of the cosmos, not only reflecting its order in their own physical, mental and spiritual structure; but at the same time they can create the order of their lives on their own. This concept continues the human self-empowerment which started in antiquity. Does it consequently lead to the modern idea that humans are entitled to be the masters and owners of nature? The early modern humanism still put human empowerment into the limits of divine cosmological order where every being has its proper place. Only if this (in our eyes) 'nonnatural' or divine order is dissolved, the extraordinary position of man in nature gets the character of unlimited domination. Only then man becomes entitled to dominate nature by calculation, by means of the methodological rationality of knowledge and its technological application, or - in the words of Max Weber "that one can in principle master all things by calculation"??

In a historical perspective of this kind the world of modernity appears as a world of human domination over nature, in which nature is only a matter of appropriation. I would like to illustrate it by a slogan which qualifies the basic cultural value system for modern societies: It's the threefold values of liberty, equality and property. This holy trinity of the modern secular world expresses the guidelines of human agency as follows: All humans are equal in the liberty to acquire property. Property is the result by appropriating nature. Appropriating nature is done by exploiting it as means to realize human purposes. In this cultural context nature is an object of exploitation. It becomes

8 G Pico della Mirandola, Oratio de hominis dignitate. Rede über die Würde des Menschen. (Lateinisch-deutsch. Edited and translated by G Von der Gönna, Reclam, Stuttgart. 1997), p. 9; For an electronic version see G Pico della Mirandola, Oration on the dignity of man at http://www.cscs.umich.edu/ crshalizi/Mirandola/ (accessed 2006.11.27).

9 M Weber, "Science as a vocation" in HM Gerth, CW Mills (Eds), From Max Weber: Essays in Sociology (London 5th ed. 1964), p. 139; [Max Weber, Wissenschaft als Beruf 1917/ 1919 - Politik als Beruf 1919 (Studienausgabe der Max-Weber-Gesamtausgabe, Bd. I/ 17).Tübingen: Mohr/Siebeck 1994, p. 87. 
exploited in three dimensions: Cognitively by science, practically by technology and socially by economy. Nature has lost its internal divinity, its quality to include cultural-like elements of meaning and significance for the human world. In this radically naturalized form nature has become a raw material which has to be formed only by man. It has no inbuilt values. It is silent and has to obey the human language.

Is this the hidden core of humanism? The anti-humanist philosophy of the 20th century answers this question positively. It criticizes humanism as an ideology, which covers the real forces of human selfempowerment, namely the naked and brute will of power with a veil of morality and norms. Karl Marx, for instance, criticized the idea of human rights as a simple ideology which allows a capitalistic exploitation of man by man. ${ }^{10}$ Human and civil rights are only rules of law which entitle the members of civil society to pursue their brute interests in gaining property. (By the way: The declared anti-Marxist intellectual of civil society, Max Weber, has a very similar understanding of human rights. ${ }^{11}$ )

Is humanism therefore nothing but an ideology of human self-empowerment to govern the world, to exploit nature and to rule the human world according to its own purposes? The answer to this question depends upon the understanding of these purposes. Nietzsche presented a very radical and simple understanding: The purpose of human self-empowerment in its relationship to nature and the human world as well is the empowerment itself. The will to power, which inspires all cultural procedures of human empowerment, has only one purpose: its own self, its growth. Values and norms are only the means towards this increase, but not the end result.

Arguing in this way the fundamental humanistic argumentation is given up, to the effect that human life cannot be pursued without the validity of values, norms and rules. The driving force of human selfempowerment is then given a natural or at least a quasi-natural quality. But is that plausible? Is the will to power in human life really blind and only related to itself? A simple look at practical life can problematize this presupposition: The mental forces driving human activity are always shaped or influenced by purposes, intentions and culturally articulated needs. What is the specific human character of the action driving will? It's not at all its blindness; on the contrary: It is its intentionality which - so to speak - eyes its object and cannot be

10 K Marx, "Zur Judenfrage" in K Marx and F Engels, Werke, Band 1, (Dietz , Berlin, 1972), pp. 347-377.

$11 \mathrm{M}$ Weber, Wirtschaft und Gesellschaft. Grundriß der verstehenden Soziologie. Studienausgabe (Ed. von Johannes Winckelmann. 2 Bde. Kiepenheuer\&Witsch, Köln, 1964), pp. 921 sp. 0.

TD, 2(2), December 2006, pp. 265-276. 
described without a reference to normative elements of cultural orientation.

Humanism is an elaborated and historically deeply rooted form of this cultural orientation. It emphasizes the competence of every human being to bring about its competence for this orientation by a special activity. We call this activity by a German name: Bildung, which I would like to translate not as 'education', but as 'self-cultivation'. This 'Bildung' means indeed self-empowerment, but an empowerment to receive the power of value-guided activity. And the basic value of this guidance is humanness in itself. It bears that already mentioned quality of being a human being, which Immanuel Kant described in such a logical clarity: in all cultural life-forms every human being has to be treated as a purpose in itself and not only a means for the benefit of others.

\section{Humanism and environment - Back to nature or forward to culture?}

Has this humanism any impact on the environmental problems of today?

At first glance we could answer 'no'. There are two reasons for this 'no'. One is the fact that humanism as I have presented it here is a typical Western cultural development, whereas the ecological problems of today are global. In its own understanding Western humanism is universalistic, but whether this universalistic approach is valid in respect to cultural otherness is an open question. ${ }^{12}$

The second 'no' refers to the non-natural quality humanism attributes to the human life form. Humanism fundamentally distinguishes human life from nature. This distinction can be understood as one of the main cultural causes for the disturbed relationship between man and nature in the ecological crisis of today. As much as non-Western cultures refer to a different understanding of humanity without this gap between humankind and nature, this second 'no' confirms the first one. Referring to such a different cultural tradition, humanism is out of the game of ecology. This indeed is an issue in the current discussion about our understanding of the relationship of humankind and

12 Without any doubt there are humanistic traditions in other cultures as well. Even more: Some intellectuals are convinced, that there is a universal element of humanism in all cultures. Wole Soyinka e.g. speaks of a "simple humanism, which is the common denominator of all civilizations". He finds it expressed in the words of Jeremy Cronin: To live close to every tree, which you ever have planted. Our century has been its greatest destroyer." W Soyinka, "Die Angst, das Unersetzliche zu verlieren" im Blätter für deutsche und internationale Politik, 3, 2006, pp. 337-344 (cit. p. 344) [my translation from the German text]. 
nature. Many intellectuals look for paradigms to which they can refer if they want to replace the Western gap between humankind and nature (creating the human attitude of dominating, subjugating and exploiting nature). In doing so, they rather often refer to non-Western paradigms which emphasize a balanced relationship or even a harmony between humankind and nature. A typical example of this replacement of the Western understanding of humankind can be found in Huang Chun-Chiehs paper on Confucianism for this conference. ${ }^{13}$ Another example is the new emphasis on so-called 'indigenous knowledge' of the people who have been colonized by the West and understand themselves as victims of this attitude of subjugation and exploitation.

Should we then give up our claims for humanity in favour of a new vision of the nature of humankind as an integrative part of an encompassing natural order of our lives?

There is a lot of sympathy for this tendency of a fundamental return to nature in understanding the environmental or ecological dimension of human life as a fundamental condition for the survival of humankind in general.

Should we give up our attitudes of self-empowerment in favour of another logic of the human relationship to nature - the relationship of harmony and brother - or sisterhood or even the relationship which refers to the general motherhood of nature?

I think that all these tendencies are sympathetic and heart-warming romanticisms with an inbuilt failure. The failure is rather simple, and because of its simplicity it's even fundamental: There has never been a human relationship to nature without elements of technologically mastering the natural conditions for human life. Every so-called indigenous knowledge is full of the techniques of this approach of mastering. Magic for instance is such a technology; and human life in general can't be lead without appropriating nature to the human world by labour, and labour means to change nature into a means for human purposes.

Additionally, the criteria of balance and harmony run against elementary experiences of humankind in all places and times: Nature is a challenge and a potential danger for man. It is full of catastrophes, it is the permanent challenge of contingency which has to be brought into an idea of order by cultural processes of human sense generation. Finally, all sympathetic romanticism fails vis-à-vis the simple fact, that we cannot solve any ecological problem of today without referring to natural science and modern technology. This, however,

13 See Chun-chieh Huang, See Man and Nature in the Confucian Tradition: Some Reflections in the Twenty-first Century, in this journal.

TD, 2(2), December 2006, pp. 265-276. 
means to confirm their inbuilt relationship to nature. In the realm of natural sciences and modern technology, nature has no meaning and does not give any hint of an order which can orientate related human activity. The idea of an order of nature is an essentially cultural input.

The most prominent form of imposing order on nature after its disenchantment by modern cognitive rationality is the aesthetisation of nature. But can an aesthetisised nature play a role in a frame of reference for our practical relationship to nature in economy for instance? That is an open question.

Traditionally aesthetisation is a compensation for the loss of meaning and sense in the modernizing process of disenchantment brought about by the increasing importance of methodical rationality in science and technology. I do not see that such compensation can really fill the place of order which it only compensates. But on the other hand I think that an aesthetisised order of nature may give us a hint at the direction we have to follow when we speak about environment and ecology. Indeed, we can experience nature as being beautiful. (This is evident here in the Kruger Park.) Kant in his "Critique of Judgment" already looked at this beauty as a hint to a non-cognitive and nontechnological relationship between man and nature. By aesthetisation nature gains a humane quality, and with this quality it even can fulfil practical functions in human life. Man has to destroy nature in order to life by it. This is evident in daily life. Eating is such a destruction. But not all human use of nature is destructive. Nature can be preserved and function as an element of human culture. Again the Kruger Park is a good example. It pays to preserve nature for a genuine human experience. Whale watching can substitute whale-killing. ${ }^{14}$ But such aesthetic relationships to nature cannot replace the other one where man has to appropriate nature for his or her biological life. It only shows that the human relationship to nature in modern times is not necessarily destructive.

But in order to find a convincing idea of how to orient our activities in the ecological dimension of our lives we have to take up this hint and at the same time we have to transcend the limits of aesthetics. Traditionally the category of fiction indicates these limits. The order of nature is a fiction if it runs against the experience of its unbalanced contingent and challenging character in human life.

What we need is a trans-aesthetic idea of the human relationship to nature, in which the human nature is seen as a synthesis of nature and culture, as a bridge combining both into a coherent life form, namely our human life form. This is the most important challenge to

14 Cf. the paper by Elise Tempelhoff, presented at this conference. (Will be submitted for peer review en possible publication in a later issue of $T D$ - Editor.) 
our interpretation of nature and of ourselves. We should no longer emphasize the gap between humanity and nature, but its togetherness, its interrelatedness.

We should start from the elementary human life form which always has already integrated nature simply by the human body. Our body is the natural place of manifesting culture; it is a necessary condition of bringing it into existence, of coining a human face onto nature. By the body pre-given natural circumstances of human life are transformed into an appropriated ones.

This transformation has a temporal perspective. Thematizing this temporality or historicity, we have to ask anew for the evolutionary process which combines human history and natural history into one encompassing procedure. Doing this we follow the track of argumentation, one of the leading German humanists in the axial time of modernity, the $18^{\text {th }}$ century, Johann Gottfried Herder has left to us. ${ }^{15}$

But this argumentation leads us to an open question and an unsolved problem. Till now the evolutionary process as a matter of the history of nature has been interpreted without any reference to elements of sense, meaning and significance as they are effective in human life. ${ }^{16}$ The biological idea of evolution does not include any element of meaning which can be picked up and introduced into the cultural framework of human world view, of understanding nature and the human world. On the other hand the usual patterns of human history refer to criteria of historical sense, which exclude nature, at least in its reference to the non-natural character of the constitutive factors of human culture.

A renaturalisation of human culture is no solution, because it excludes convincing sense criteria as long as we take seriously our scientific and technological relationship to nature. On the other side a culturalization of nature is no solution as well. It would put the whole realm of nature under the category of culture which has been developed to indicate the difference between the natural world and the human world with its values and norms and patterns of meaning, sense and significance.

So at the end of my argumentation I present an intellectual embarrassment. But that should not lead us into despair and intellectual escapism (like pseudo-natural romanticism or a culturalism in understanding nature). Instead, it should encourage us to look at

15 Cf. P Hanns Reill, Ritalising nature in the Enlightenment. (University of California Press, Berkeley, 2005.)

16 A remarkable exemption is G Hüther, Die Evolution der Liebe: Was Darwin bereits ahnte und die Darwinisten nicht wahrhaben wollen, (3. Aufl., Vandenhoeck \& Ruprecht, Göttingen, 2003). 
human nature as an already achieved synthesis of nature and culture. I understand this argument as a plea for a humanism which may overcome the distinction between humankind and nature not by ignoring their difference, but by looking at their synthesis in an encompassing temporal perspective.

Within such a perspective humanism becomes mediated if not reconciled with nature. When coping with this task humanism enters a new epoch of its development. It can keep up its traditional reference to nature as a potential for the cultural achievements of humankind. At the same time humanism gets a new future perspective within which it gains a new transcultural universalism. Since nature, which has to be re-integrated into culture, is shared by all human beings it is fundamental that 'culturalization' has to be understood as being transculturally universalistic. We humans start our lives as cultural beings in the same way. Before we become culturally different (mainly by language) we are already the same cultural beings. We share the constitutive abilities of the human mind which distinguishes us from animals. ${ }^{17}$ On the level of intercultural discourse today this common ground has not yet sufficiently explicated. We may and we should find ourselves as humans again by sharing common humanity not beyond but within our cultural diversity and plurality. This new humanism is a necessary cultural condition for solving the ecological problems we all are endangered by.

17 Cf. M Tomasello, Die kulturelle Entwicklung des menschlichen Denkens: Zur Evolution der Kognition, (Suhrkamp, Frankfurt am Main, 2002). 